\title{
EXAMINING THE IMPACT OF EU COHESION POLICIES AIMING TO REDUCE REGIONAL AND SOCIAL DISPARITIES WITH EXAMPLES OF POLICY IMPACTS IN IRELAND
}

\author{
Brendan Williams, Johanna Varghese \\ School of Architecture Planning and Environmental Policy, College of Engineering and Architecture, University \\ College Dublin. \\ Stillorgan Rd, Belfield, Dublin 4: Ireland \\ brendan.williams@ucd.ie,johannavarghese@gmail.com
}

\begin{abstract}
This research describes the evolution of the Irish spatial planning system and explores the impact of EU cohesion policies aiming to reduce regional and social disparities within the European Union with respect to recent developments in Ireland. The changing nature of the Irish planning system is seen as movement from a market or local development led approach towards a more strategic regional and national approach. This trend has in part been influenced by EU policies, directives and initiatives with evidence of both difficulties and successful delivery of some major projects. The discussion is complemented by evidence from two case studies in the transportation area and interviews with key participants in the policy processes. In conclusion the implications of such trends for future planning policy in Ireland and the EU are explored.
\end{abstract}

Key words: EU, Ireland, spatial planning, transport infrastructure, peripheral regions.

\section{Introduction and planning context}

This study assesses trends in spatial planning in Ireland, changes in territorial governance and spatial planning systems and reforms from 2000 to 2018 and reasons for these changes with specific reference to EU directives and policies. In particular, the research examines critical regional development projects/case studies assisted by EU cohesion funding and policies. This research is intended to assist in developing a stronger relationship between priorities and measures of EU operational programmes and local and regional planning policies and instruments in Ireland, including a regular ex ante, ongoing and ex post evaluations of the territorial impact of a programme. The basis for our policy analysis and recommendations is to improve spatial planning practice in Ireland and Europe based on emerging evidence of best practice and to achieve a more effective EU relationship with spatial planning. Ideally spatial planning practice intends to become more transparent and cost-effective maximising the social and economic benefits of investments made. 
Irish physical planning has previously operated in a highly localised manner with a passive ambit of operations with planning powers were legislated for and a regulatory system which evolved based on a development led approach. This system in common with common law jurisdictions such as the UK, Australia and parts of the USA emphasises common law property rights. This local land use planning typology has three principal elements: a local plan-making function, a developmental function involving issues such as land servicing, and a regulatory or control function. These functions are often carried out in distinct departments of a city, regional, or national authority, leading to fragmentation in both the evidence upon which decisions are based and actual decision-making (Tosics et al. 2010; Williams et al. 2016).

In Ireland, the structures within which the planning system historically operated is the fragmented local authority system largely unreformed since the nineteenth century. As the system has moved in recent decades towards considering the planning futures on a regional basis this needs considerable integration of data and analysis of trends to understand trends on a regional basis.

Statutory planning in Ireland has largely acted as an indirect policy measure in terms of facilitating the development of new commercial and residential urban areas. Due to resource limitations planning functions are dominated by development control functions. Spatial planning activities therefore are a secondary factor in development activities, playing a facilitative rather than a causal role. Following the great financial crisis and the property market collapse there has been a significant breakdown in trust and failure of participatory democracy as it relates to planning and development issues.

The weaknesses of the planning system in Ireland in the past can be categorised as an example of passive land management which was flexible and facilitative rather than active land management. There is a need now to move from a sole emphasis on local physical planning and land use rights to consideration of broader development impacts now and in the future. This necessitates development of capacities for policy makers and development actors to consider the future impacts of today's development decisions in the context of future development outcomes and scenarios as outlined in the National Planning Framework (NPF).

The planning system in Ireland involves a legally based process, with conflicting views potentially contested at plan adoption, application, or appeal stages by interested parties. Central administrative control is an entrenched feature of the regional policy framework in Ireland. Financial and administrative powers are essentially centralised and local government acts as agent of national government rather than autonomous.

Existing resources and infrastructure is relatively fixed in the medium-term and the need for effective urban management is consequently greater than before. In particular, the negative effects of rapid growth are quickly felt in the Dublin Region as infrastructure constraints led to congestion and affordable housing problems. As the long-term future of the urban region is intrinsically linked to urban environmental quality, it is essential that a co-ordinated and integrated response be developed to the city region's infrastructure, land-use and economic development pattern. A number of problems have persisted through attempts to reform the planning system including the following:

- the absence of effective co-ordination amongst principal stakeholders;

- competition for resources and revenue amongst the individual affected local authorities who remain the statutory planning authorities for the region;

- the under-estimation of the scale, pace and immediacy of the economic growth experienced in Ireland. 


\section{The role of EU policy and directives in Irish planning}

Cohesion policy, EU directives and European Spatial Development Perspective strongly influence Irish spatial planning and territorial governance during the period $2000-2016$. This can be immediately seen as the changing priorities of regional investment in Ireland match thematic objectives of cohesion policy for each period, for example between 2007-2013 the themes were innovation and knowledge economy, environment and accessibility and support for enterprises. However implementation can be problematic or time delayed as the economic crisis in Ireland over that period stymied the priority of 'sustainable urban development' due to a lack of financing (Southern Regional Assembly 2017a).The National Development Plan (2000-2006, 2007-2013) which included national road networks and regeneration programmes was funded in part by cohesion funds. In addition, European structural funds have contributed to projects such as Dublin's light railway system, bus corridors, re-use of buildings for public use and broadband technology (Smyth 1998).Many local development programmes and projects continue to be funded by PEACE, LEADER and INTERREG facilitating diverse rural communities to develop and implement projects suited to their needs.

It is in the area of national and regional strategic planning that the EU influence is pronounced; the first planning strategy on a regional basis, the Strategic Planning Guidelines, dates from 1999. The planning system was reformed by the Planning and Development Act in 2000. Moreover, sustainable development has taken a more important part during these years in the Irish public policies.

The National Spatial Strategy (NSS, 2002-2020) adopted and adapted concepts from the European Spatial Development Perspective such as 'balanced regional development', 'gateways' and 'hubs'. This developed from the Strategic (regional) Planning Guidelines. This developed the role of spatial coordination to include concepts such as balanced spatial development, urban rural relationships, polycentric development, and spatial level coordination of public policy. It also included linkages with national development planning and investment decisions. The regional spatial plans developed included multiple gateways hubs in an attempt to prioritise regional balance and promoted such alternative growth centres as counter acting of the development occurring in the Greater Dublin area.

Political commitment to the NSS was immediately in doubt in 2003, when in a politically motivated decision, the then central government selected multiple urban and town centres for decentralisation of government offices and functions without relating such policies to the official selected centres as set out in NSS. This proposal (partially completed only) was to shift over 10000 public service jobs and their offices to over 50 urban centres. Other indicators of conflicts with key strategies of the plan included the continued favouring of dispersed housing through rural housing guidelines in 2005 and extensive land rezoning on green field areas. When the speculative housing bubble eventually crashed in 2009 with the great financial crisis the NSS was effectively abandoned by the incoming new government.

The replacement for that national planning strategy is the National Planning Framework (NPF) launched in February 2018 which is outcome and target based e.g. brownfield and vacant sites targets have been set nationally and locally. Targets stated include $40 \%$ of new housing to be built within existing built up areas but to date it is unclear what sanctions if any exist where targets not achieved. The NPF promotes a more compact urban form now moving the debate on urban and regional development form to national objectives in place of purely local growth issues. This represents a significant change in ambition from the historically highly localised form of planning 
where local political interests were often strongly pro-development and directly encouraging or facilitating housing, retail and service development in peripheral or ex urban areas.

Significant pressures remain on any the implementation of proposed changes with a continuation of construction industry lobbying to boost quantities of development and pressures to reduce specific standards and requirements such as in the official new apartment design guidelines (Department of Housing, Planning and Local Government 2018). Such pressures are also seen in moves towards flexible performance based design standards to give greater regulatory flexibility and away from fixed development standards and regulations.

The aim of rationalising regional planning structures is seen in regional levels of administration being reduced from 8 to 3 authorities who are now responsible for Regional Spatial and Economic Strategies which are being developed with a 50/50 distribution of economic growth between Dublin and the other two regions to counterbalance development pressures on Dublin.

The NPF makes a direct connection between infrastructure and regeneration projects funded through the National Development Plan (NDP) published along with NPF to stimulate the wider regional economy the Urban and Rural Regeneration Funds that were launched in July as part of Project Ireland 2040.

This increases the role of central government with the National Development Plan to the fore and the NPF operating in tandem with its proposals. This sees planning activities as development enablement and facilitation rather than balancing the conflicting interest of society.

Some additional resources are clearly indicated such as the provision made in the NDP for 2 bn euro to 2027 for the urban fund and 1 bn euro to 2027 for the rural fund, to support implementation of the NPF. These plans are overseen by the Department of Finance and Public Expenditure and Reform taking a direct and proactive role in national spatial planning.

The non-compliance of local authorities with regional policy in the previous National Spatial Strategy was acknowledged after a High Court case (McEvoy \& Smith vs. Meath County Council 2002) which challenged the action of a local authority that failed to 'have regard' to the strategic planning guidelines when adopting their local plan. ${ }^{1}$

As the documents did not have sufficient regulatory compliance order, all-government support, leadership and the legal basis for implementation was very weak. The Strategic Planning Guidelines (1999) preceded the Regional Planning Guidelines and will be followed by the Regional Spatial and Economic Strategy (RSES) being developed by the new co coordinating regional authorities. This process is underpinned by the Planning and Development Act 2016 and for the first time the word 'economic' is used alongside 'spatial' in a regional planning strategy in Ireland'. The present government hopes to get the new National Planning Framework 2040 (draft phase - public consultation stage) and supporting regional strategies passed so that it becomes the statutory basis for managing future development in Ireland (Coveney 2017). Both the draft national and regional strategies are rich in statistics and evidence-based data and represent a shift to more evidence-based policy making.

\footnotetext{
${ }^{1}$ Section 27 (1) of the Planning and Development Act of 2000 provides that: "A planning authority shall have regard to any regional planning guidelines in force for its area when making and adopting a development plan". The High Court ruled in favour of the local authority as the judge stated that "To have regard to" did not mean "slavishly to adhere to". It requires the planning authority to consider the development plan, but does not oblige them to follow it. Subsequently in the Planning and Development Act 2010 the wording was changed and the concept of core strategy was introduced, requiring compliance of local development plan with regional plans and national strategy(http://www.lwig.net/Research/Legal/Quirke-Judgement-McCoy-and-Smith-vs-Meath-CoCo.pdf).

${ }^{2}$ Before there were two separate documents - Regional Planning Guidelines and Regional Economic Strategy.
} 
In 2015 the former regional assemblies NUTS 2 (Border, Midlands \& West and Southern \& Eastern) were restructured (Fig. 1). Three new NUTS 2 regional assemblies were formed. Eight regional authorities responsible for NUTS 3 areas were dissolved (June 2014) ${ }^{3}$ removing the governance structure of regional authorities at NUTS 3 level (Table 1). Regional authorities' staff joined the new regional assemblies, strengthening the organisation and competences of regional assemblies. The new regional assemblies manage over $76 \%$ of the EU budget with national and regional authorities through a shared management system through 5 EU funds ${ }^{4}$ (Southern Regional Assembly 2016). Each region produces a RSES that has a set of investment priorities to meet the strategic objectives of the region, aligning compliance between Territorial Agenda 2020, EU directives, RSES, national spatial strategy, local development plans and local economic community plans of local authorities to ensure compliance with identified local and regional needs (Southern Regional Assembly 2017b).

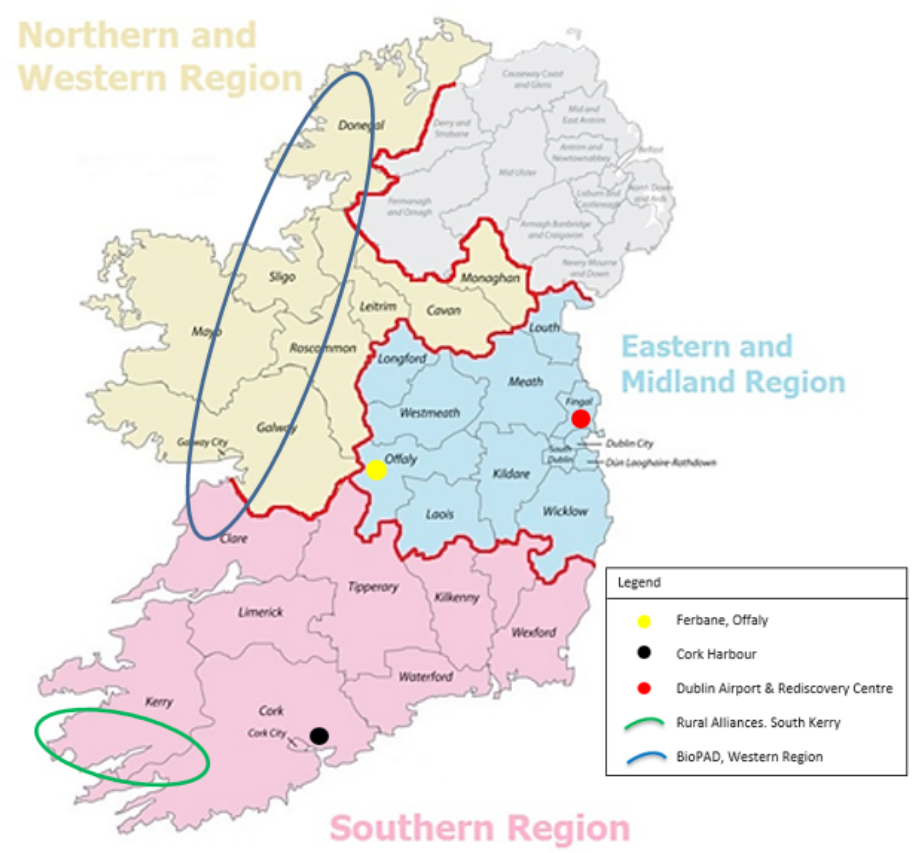

Figure 1. NUTS 2 regions in Ireland (January 2015)

Source: adapted from Eastern Midland Regional Assembly (2017: 1).

The region is sub-divided into three Strategic Planning Areas and separate strategic planning area committees have been established in respect of each strategic planning area within the region. The membership of an assembly is predominantly nominated by local authorities to represent the region. These committees are set up to assist the Assembly with the development of policy

\footnotetext{
3 Eight NUTS 3 strategic planning areas: 1. Dublin, 2. Midland, 3. Eastern, in Eastern Midland region, 4.Northern(Border), 5. Western, in Northern \& Western region, 6. South East, 7. South West, 8. Mid-West, in Southern region.

${ }^{4}$ European Regional Development Fund (ERDF) - regional and urban development, European Social Fund (ESF) social inclusion and good governance, Northern and Western region - economic convergence by less-developed regions, European Maritime Fisheries Fund, European Agricultural Fund for Rural Development (EAFRD) (http:// www.southernassembly.ie/resources/faqs).
} 
and advise the Assembly generally on matters in relation to regional spatial and economic strategy at a sub-regional level (Southern Regional Assembly 2017b).

The regional assemblies focus on preparation and implementation of RSESs, integration of Local Economic and Community Plans (LECPs), management of EU operational programmes, EU project participation, implementation of national economic policy, and working with the National Oversight and Audit Commission (Eastern Midland Regional Assembly 2017). They also assist to "source European funding for regional operation programmes, promote coordinated public services, monitor proposals that impact on their area and advise public bodies of the regional implications of their plans and policies" (Department of Housing Planning and Local Government 2017).

Regional assemblies prepare operational programmes ${ }^{5}$ in the context of the:

- Europe 2020 goals of smart, sustainable and inclusive growth,

- cohesion policy 11 thematic objectives, in particular 4-76 due to funding conditions,

- Strategic Framework for European Structural and Investment Funds 2014-2020,

- EC regional policy priorities.

Table 1. New NUTS 2 regional structures for Ireland and dissolution of NUTS 3 authorities (January 2015)

\begin{tabular}{|c|c|c|}
\hline New structure & Old structure & $\begin{array}{l}\text { Implications of the structural } \\
\text { changes }\end{array}$ \\
\hline $\begin{array}{l}\text { Regional assemblies (NUTS 2) } \\
\text { create RSES and manage EU funding } \\
\text { for EU projects. }\end{array}$ & $\begin{array}{l}\text { Regional assemblies (NUTS 2) } \\
\text { administer regional operational } \\
\text { programmes. }\end{array}$ & $\begin{array}{l}\text { RSES - the first time that spatial } \\
\text { strategy and economic strategy } \\
\text { are merged into one regional } \\
\text { planning document. }\end{array}$ \\
\hline $\begin{array}{l}\text { RSES preparation is instructed } \\
\text { by the Minister of Housing Planning } \\
\text { Community and Local Government. } \\
\text { Information about its form } \\
\text { and content is included } \\
\text { in the Planning and Development } \\
\text { Act } 2016 .\end{array}$ & $\begin{array}{l}\text { Before } 2015 \text { the role of regional } \\
\text { assemblies was to consider } \\
\text { "from time to time, the reviews } \\
\text { of the development plans of local } \\
\text { authorities in the region as carried } \\
\text { out by the relevant regional } \\
\text { authorities" (Grist 2012). }\end{array}$ & $\begin{array}{l}\text { All RSES programmes } \\
\text { are synchronised to cohesion policy } \\
\text { thematic objectives for growth } \\
\text { period } 2014-2020 \text { and to ERDF } \\
\text { funded main priorities } 1-4 \text {. }\end{array}$ \\
\hline $\begin{array}{l}\text { RSES works with Local Economic } \\
\text { Community plans of local } \\
\text { authorities within its region. } \\
\text { Regional authorities (NUTS 3) } \\
\text { dissolved and staff transferred } \\
\text { to regional assemblies (NUTS 2) } \\
\text { Regional Assemblies create } \\
\text { Metropolitan Area Strategic Plans } \\
\text { for regional cities within their } \\
\text { region. }\end{array}$ & $\begin{array}{l}\text { Before their dissolution in June } \\
\text { 2014, regional authorities (NUTS } \\
\text { 3) produced regional planning } \\
\text { guidelines which until } 2010 \text { had } \\
\text { very weak compliance order } \\
\text { with local authority development } \\
\text { plans. }\end{array}$ & $\begin{array}{l}\text { There appears to be progress } \\
\text { towards more compliance } \\
\text { between national, regional } \\
\text { and local level, if the draft National } \\
\text { Planning Framework } 2040 \\
\text { is adopted and if it is supported } \\
\text { by real economic budgets, political } \\
\text { leadership and an 'all-government' } \\
\text { buy-in. }\end{array}$ \\
\hline
\end{tabular}

Source: authors' own elaboration.

\footnotetext{
${ }^{5}$ The operational programme is a document which sets out the approved investment programme for the region which is co-funded by the EU and includes among other things investment priorities, financing plan and implementation arrangements (http://www.southernassembly.ie/resources/faqs)

${ }^{6}$ See: http://ec.europa.eu/regional_policy/en/policy/how/priorities.
} 
The new clustering brings the Midland region and a Border county into the Eastern Midland (Greater Dublin) region. The rationale for the new way the regions are grouped is not clear (Riordan 2017). One of the regional assembly websites state "...together the regional assemblies form a strong regional structure that strengthens the development of Ireland's regions in a coordinated, strategic manner..." (Northern and Western Regional Assembly 2017a). A noticeable change is the much improved accessibility to relevant content on EU funding on their websites - that show the connection between EU funds regional operational programmes.

Within the regions the characteristics from one county to another differ widely, apart from the Northern and Western region which is predominantly peripheral as a region with the exception of Galway city. Within the other two regions (Eastern Midland and Southern), there are pockets with characteristics of peripherality which include declining and aging population, lack of access to good quality infrastructure and new technologies and in particular to Ireland, an absence of a mechanism to remove bureaucratic barriers so that unique local programmes can be delivered to specific communities (O'Keefe 2017). Both the Eastern Midland region and the Northern and Western region contain areas with the lowest average disposable income per person ${ }^{7}$.

The overall urban structure in Ireland is weak and the balance of growth between the three regions is very poor. Regional cities like Cork and Galway are growing but at a relatively slow pace (Department of Housing, Planning and Local Government 2017). Both Cork and Dublin have well educated, young thriving population, employment in IT, financial services or high tech industry with global recognition and reach. However each also has areas of deprivation with population dependent on diminishing public and civil services, housing under-provision, underemployment or unemployment confined by long standing geography of poverty (Cork Equal and Sustainable Communities Alliance 2015).

As an island, the international airports and ports are key nodes of connectivity with Europe and the world and play a crucial part in the country's competitiveness and future prospects. The key ports and airports are state owned commercial entities with the capacity to raise their own finance including loans directed through cohesion policy such as European Investment Bank and Connecting Europe Facility (CEF). Tier 1 ports like Dublin and Cork account for $80 \%$ of national port freight traffic, and their significance is indicated in the National Ports Policy and RSES (Department of Housing, Planning and Local Government 2017). Following the National Development Plan (2000-2006) through cohesion funds, connectivity to Dublin from most regions improved considerably (McHenry 2017). Connectivity between other regions requires strengthening to reduce dependency on the Dublin region.

\section{Main areas of EU cohesion policies impact on spatial planning}

\section{Transport infrastructure and accessibility}

The thematic issues are:

- traffic congestion in the Greater Dublin Area in particular the ring road (M50) on the periphery of Dublin;

- public transport - rail, metro, and bus;

- connectivity to rest of Europe and world through airport and ports;

\footnotetext{
${ }^{7}$ The Border (19233 euro) and Midland (19345 euro) regional authority areas fared worst among the eight regions (http://www.southernassembly.ie/regional-planning/statistics).
} 
- active transportation - cycling and walking and health;

- connected issues of urban sprawl, GHG emissions, and quality of life.

Through cohesion policy and the National Development Plan 2000-2006 (NDP 2000-2006), Ireland invested in road infrastructure connecting the different regional cities with Dublin and improved accessibility to rural areas. During the economic boom, despite county and city councils' policy of clustering new development within or in close proximity to existing towns and villages, many new housing estates and individual houses were built on the outskirts of urban centres or in the neighbouring countryside. The landscape has been altered by urban sprawl in mainly low densities at various locations (Teagasc 2014).

As Dublin continues to grow as a major economic engine the issues of dispersed development of the region, low density cities which are uneconomical for high capacity public transport and inconsistent funding (due to the economic crisis) for public transport developments are ongoing challenges. Traffic congestion and trips increase as the economic recovery improves (Graham 2017). In response to the transport issues in the Dublin and eastern regions, the National Transport Authority was formed in 2009 to produce transport strategy for the Greater Dublin Area.

Monocentric development of other smaller regional cities echo similar issues in Dublin at a smaller scale. Market led residential development in the suburbs leads to movement of labour force from dormitory towns to cities leading to traffic congestion at peak times and increased GHG emissions. Long term challenges exist in terms of retrofitting sustainable design into existing developments and roads and how to change behaviour towards more sustainable private transport.

Delivery of public transport and improving networks, narrowed in scope during the economic crisis, creating a significant lag in its implementation as it is demand forecast led and relies on economic capacity. Currently there are completed residential and commercial developments awaiting infrastructure such as Metro North, Dublin (Fallon 2017) or incomplete developments with public transport infrastructure such as Adamstown, South Dublin. The legacy of the economic boom (urban sprawl) and transition to a more service-oriented economy (located in urban centres or urban fringes) contribute to longer commuting distances and a car dominated transport system (EPA 2011).

Rail connection Cork - Dublin - Belfast was implemented through TEN-T and national motorways through the NDP 2000-2006. However, there are high costs of connecting inter-regional rail and bus services with rural towns due to the low populations served. An estimated $45 \%$ of rural district electoral divisions in Ireland have a minimal level of scheduled public transport service. In particular, a dispersed settlement pattern and one-off housing exacerbate the issue (EPA 2011).

Major investment and expansion were undertaken in Dublin airport and upgrading of Tier 1 ports directed through cohesion policy in the form of loans from European Investment Bank and CEF. Issues regarding the environment, habitats and biodiversity dictated their scale of expansion. During the economic crisis there was a shift in attitude towards active transportation. This was matched by National Transport Strategy and local authority led bike share schemes, cycle lanes and inclusion of the concept of green infrastructure and the connected (walkable) city in the development plans of Dublin, Cork, Limerick and Galway, which aligns with cohesion fund objective $7^{8}$.

The National Spatial Strategy (2002-2020) and Regional Planning Guidelines were not seen as effective in implementing balanced regional development or creating critical mass outside the Greater Dublin Area (EPA 2011). The newly proposed RSESs for the new NUTS 2 regions and the National Planning Framework 2040 provide more evidence based data and mapping that links regional investment priorities with capital investment (Northern and Western Regional Assembly 2017b).

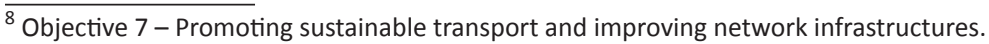




\section{Peripheries and other specific regions}

Ireland is the most rural of the EU27 countries for both population and land area ${ }^{9}$ under the OECD definition. Northern and Western Region, Southern Region and Eastern Midland region under different definitions of rural (Central Statistics Office - CSO, National Planning Framework - NPF and Commission for the Economic Development of Rural Areas - CEDRA) showing the Northern and Western region as the most rural region between $(66.1 \%, 82.7 \%$ or $90.9 \%)$ in Figure. 2 as argued by McHenry (2017). This can be compared with the OECD values for rurality which can be revised over time and include interpretations such as: predominantly rural (more than $50 \%$ of the population live in rural areas); intermediate (20-50 \% living in rural areas); predominantly urban (less than $20 \%$ living in rural areas) (Brezzi et al. 2011).

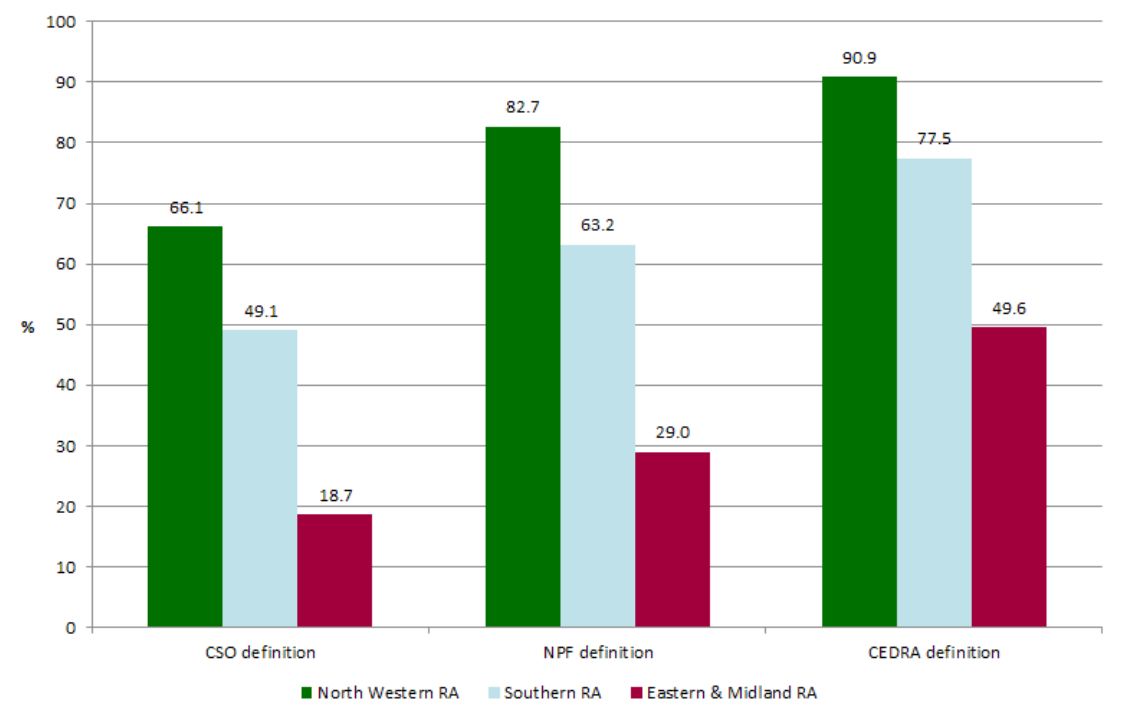

Figure 2. Comparison of percentage of the population living in rural areas in the three regions Source: McHenry (2017).

Communities in peripheral, remote areas in Ireland historically suffered extensively from a major decline in both population and economic activity during the nineteenth century. Since independence from the UK in the 1920s these areas have lagged behind economically in comparison to the Mid-West and eastern parts of Ireland. Many peripheral areas in the Midlands, Western, Northern (Border) regions did not directly benefit from the economic boom of the 1990s. While the population ${ }^{10}$ of the state has grown $3.7 \%$ from 2011-2016, rural and peripheral areas in every county continued to experience significant population decline (Gleeson 2016). These factors give rise to issues such as reduction of service delivery (post offices, police stations), a high old age cohort, fewer young people and reduced transport connectivity contributing to isolation.

\footnotetext{
${ }^{9}$ The OECD methodology classifies local administrative units level 2 with a population density below 150 inhabitants per $\mathrm{km}^{2}$ as rural. For more information on the definition http://ec.europa.eu/eurostat/statistics-explained/ index.php/Urban-rural_typology).

${ }^{10}$ Population of Ireland is 4.76 million (CSO 2016).
} 
The Pobal Deprivation Index reveals that the places worst hit by recession and post-recession (2006-2016) years were small rural towns (population of 1000 to 5000) (Ni Aodha 2017). Past patterns of shortcomings in state support, funding and political representation towards these areas exist. Decades of marginalisation have prompted several rural communities to take charge of their own development fortunes. As a result, there are high levels of innovation, entrepreneurship and a 'can-do' attitude and Ireland is characterised by a high number of community-led or bottom-up initiatives (Teagasc 2014). The region is therefore characterised by local independent cultures with a sense of self-reliance and 'necessity' entrepreneurship ${ }^{11}$ (Brennan, Flint \& Luloff 2009).

Key challenges are employment and re-skilling, and re-structuring the nature of employment (Commission for the Economic Development of Rural Areas 2017). SMEs tend to be small with a high number of microenterprises and a high percentage of one-person businesses. Management skills in human resources, marketing and finance tend to be poor. Therefore, support networks and rural enterprise policy specific to these types of enterprises in peripheral areas are important (Teagasc 2014).

The Irish government set up Údarás na Gaeltachta to promote industry in the Irish speaking areas and the Industrial Development Agency to promote the region as environments for FDI and multinational hubs that support a good quality of life. Quasi-governmental/independent agencies such as the Western Development Commission support grass roots development, place-based projects through research and development along with EU programmes including LEADER - an EU initiative to support rural development projects initiated at the local level in order to revitalise rural areas and PEACE - an EU programme supporting peace and reconciliation and promoting economic and social progress in Northern Ireland and the Border Region of Ireland. Other supports include Enterprise Ireland, Shannon development, Science Foundation Ireland, Teagasc, Failte Ireland, Local Enterprise Offices ${ }^{12}$, Community Enterprise centres; Bord Bia - Food Board and Bord lascaigh Mhara - Irish Seafood Development Agency (Bord lascaigh Mhara 2017).

One of the latest government backed programmes is the Rural Economic Development Zones (REDZ) emerging from the Commission for Economic Development of Rural Areas (CEDRA). These are functional areas rather than administrative geographic areas. The zones are defined at subcounty level where people live and work reflecting spatial patterns of local economic activities and development. By focusing on functional areas, bottom up integrated zones are created. This facilitates locally prepared plans which leverage government support through government taskforces and agencies. 52 projects were allocated a total 3.7 million in 2015 and in $2016-5.3$ million was invested in 41 projects.

Another recent initiative is establishment of a national taskforce to improve broadband and mobile coverage in the short term until the roll out of the National Broadband Plan. This support is vital for rural SME expansion in terms of network activity and connectivity of rural Ireland to Europe (Irish Government News Service 2016).

In 2016 as part of the restructuring, a new intervention, the LECPs were launched (Fig. 3). They work alongside the city and county development plans (LAU 1) in a "shared but separate process". The LECPs shall also relate to measures under the Action Plan for Jobs, report of the CEDRA. The regional assemblies access the projects and programmes of the LECP to relative to the high level EU2020 targets $^{13}$ laid out in the National Reform programme for Ireland (Department of Environment 2015).

\footnotetext{
11 'Necessity' entrepreneurs have a different perception of entrepreneurship or business ownership than do 'opportunity' entrepreneurs. They pursue enterprise opportunities, out of necessity rather than opportunity (Teagasc 2014).

12 Funded through cohesion policy ERDF.

${ }^{13}$ Ireland's EU2020 targets: Employment; Research \& Development; Climate Change and Energy; Early School Leav-
} 


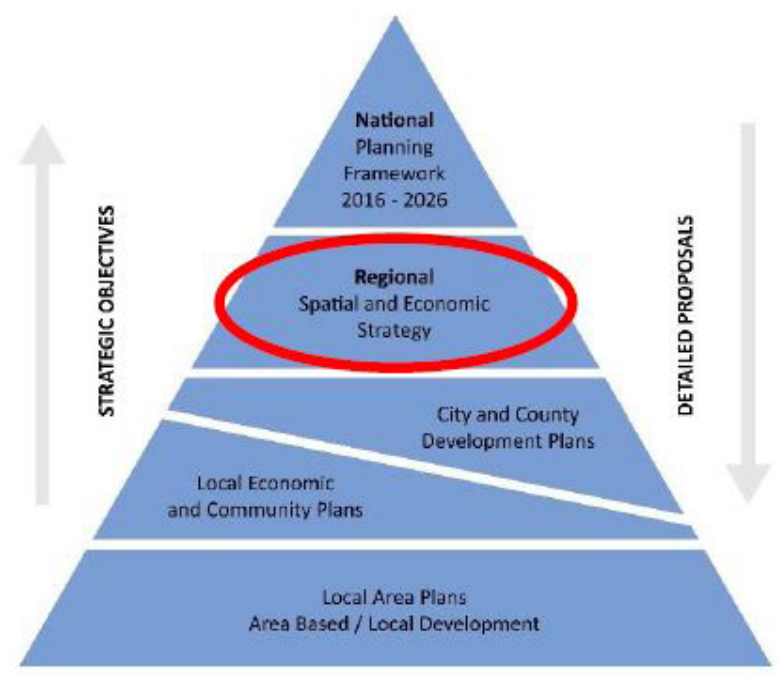

Figure 3. New structure, spatial planning instruments and position of RSES, LECP and proposed National Planning Framework

Source: Eastern Midland Regional Assembly (2015).

The Local Government Reform Act 2014 provided for a more central role for local government in economic and community development - contributing to achieving the aim in the Action Programme for Effective Local Government, “... that local government will be the main vehicle of governance and public service at local level, leading economic, social and community development" (Fingal County Council 2015a).

The LECPs are prepared by the local authority and the Local Community Development Committee (LCDC). The economic element is developed by the local authority and the community element prepared by the LCDC. Through collaboration between the local authority and community committee, the plan sets out "...objectives and actions to promote and support the economic development and local community development of LAU 1 territories. They include themes that align with cohesion policy (ERDF and ESF) priorities and are Enterprise and Employment; Learning, Training and Working; Well-being and Social Inclusion (also in line with the National Action Plan for Social Inclusion); Leadership and Community Empowerment; Tourism, Environment and Heritage; Urban Towns and Rural Communities (Fingal County Council 2016).

The LECP however, is not an operational plan. It is designed to work between and across strategic and operational plans of other agencies by identifying and implementing integrated actions, ensuring coherent actions between agencies (Fingal County Council 2015b).

Therefore the LECP is delivered by those agencies and the local authority. It is intended to be consistent with the core strategy and objectives of local development plans, aligned with the Strategic Environmental Assessment (SEA) directive and article 6 of the Habitats Directive. The relevant regional assembly ensures the consistency of the LECP with the local development plan. The responsibility of local development strategy, LEADER programmes and Social Activation Programme rests with the LCDC. 
The wide range of policy areas and types of initiatives assisted by EU cohesion and regional development initiatives is indicated below and case studies are then discussed from the Transport infrastructure and accessibility theme areas (Table 2).

Table 2. Project examples related to the main thematic issues

\begin{tabular}{|l|l|l|l|l|}
\hline \multicolumn{1}{|c|}{ Thematic issue } & \multicolumn{2}{|c|}{ Transport infrastructure and accessibility } & \multicolumn{2}{c|}{ Peripheries and other specific regions } \\
\hline Project name & $\begin{array}{l}\text { International Port } \\
\text { Redevelopment } \\
\text { and Extension }\end{array}$ & International Airport & Bioenergy deployment & $\begin{array}{l}\text { Community } \\
\text { Development }\end{array}$ \\
\hline Years of realisation & $2015-2018$ & 2010 & $2012-2014$ & 2001 \\
\hline NUTS 2 region & Southern Region & East Midland Region & $\begin{array}{l}\text { Northern \& Western } \\
\text { Region }\end{array}$ & East Midland Region \\
\hline Type of region & City Harbour & Global City & Remote Rural & Post Industrial-Rural \\
\hline Source of funding & $\begin{array}{l}\text { Cohesion Policy } \\
\text { through National } \\
\text { Development } \\
\text { Plan in tandem } \\
\text { with Connecting } \\
\text { Europe Facility } \\
\text { and TEN-T }\end{array}$ & $\begin{array}{l}\text { Cohesion Policy } \\
\text { through National } \\
\text { Development } \\
\text { Plan in tandem } \\
\text { with European } \\
\text { Investment Bank- EIB }\end{array}$ & $\begin{array}{l}\text { Cohesion Policy } \\
\text { through INTERRE IVB } \\
\text { Northern Periphery } \\
\text { Programme }\end{array}$ & $\begin{array}{l}\text { Cohesion Policy } \\
\text { through LEADER + }\end{array}$ \\
\hline
\end{tabular}

Source: authors' own research.

\section{Example of EU role in key transport and infrastructure projects}

\section{Plans, implementation and relationship between cohesion policy, spatial planning and territorial governance on an example of the Ringaskiddy Re-Development project}

Cork harbour, located in the south west of Ireland, is one of Ireland's three largest regional ports with a turnover of 29.8 million euro in 2015. Cork City is the second largest city in Ireland and the Greater Cork Area and is described by the Cork Area Strategic Plan (CASP 2001-2020) as one of the most dynamic areas in terms of education, research and development, internationally traded services and high-technology manufacturing. The region contains many multinational corporation manufacturing and European headquartered companies, particularly in the electronics, software, food pharmaceutical, bio-pharma and associated sectors. The Port plays a significant role in supporting the export led economic development of this region and the country, with traffic amounting to 11.2 million tonnes (in 2015). CASP describes the Cork City-Region as "punching below its weight" in economic development terms, despite its significant assets. One of the key issues is maximising the economic potential and continuing to attract foreign investment and skilled labour. Described the importance of the development not just locally, but regionally and nationally an interview respondent stated:

"The Development of the Port is considered regional level infrastructure. The development of the port is a problem due to peripherally, especially for the region (Southern Region: Cork, Limerick, West region) to develop economically. If you can't develop the capacity of the port you restrict the growth and development of the region as a whole. .... big change since 2000, Port of Cork was stuck, refusal would limit regional growth - export a lot from Limerick and Kerry, huge difference to Munster and regionally". 
The Redevelopment Project, within Cork harbour (Cork Harbour Project) is located in Ringaskiddy, $13 \mathrm{~km}$ southeast of Cork city centre. The project involves the transfer of major port activities from the existing Cork city port to this new site where most of the region's economic activity is based. The area surrounding the site contains pharma industrial clusters of including, Pfizer, Centocor, Novartis, Johnson \& Johnson and GlaxoSmithKlein. The re-development is the first in a series of phases that will lead to an investment of approximately 100 million euro to allow for the extension of existing facilities operating in Ringaskiddy which aim to enhance the Port as a major economic area for the city and region. The project will mean the accommodation of larger container vessels in the terminal. The expansion comprises a $200 \mathrm{~m}$-long berth and new container yard which will become operational in 2018. A respondent interviewed as part of this research indicated that there was extensive political support for the project given its importance in economic terms to strengthening the region.

Planning approval for the redevelopment was granted to the Cork Harbour Port Authority in May 2015. This was a second-round application for consent approval from the Irish Planning Appeals Board (An Bord Pleanala) who had determined that the project was Strategic Infrastructure Development under the Strategic Infrastructure Development Act of 2006. The first application was previously refused on the grounds of lack of proximity to the national rail network. The transport report on the application described the project as "representing a retrograde step in terms of sustainable transport planning (noting references to the potential for rail freight in the Regional Planning Guidelines for the South West Region 2004-2020 and the Cork Area Strategic Plan 2001-2020)" (An Bord Pleanala 2014). An interviewee stated that the application was successful because a Mobility Management Plan had been put in place by the applicant to traffic control measures "but the $2^{\text {nd }}$ phase of the Port development was conditioned to be restricted until the Dunkettle Interchange (a major road junction) was upgraded".

Chapter 7 of the National Development Plan 2007-2013 (supported by cohesion policy) recognised the economic importance of commercial ports to the economic strategy of the entire country. The plan specifically notes the need for relocation of the port to facilitate the Docklands area development in Cork. The NSS, which set out the framework for spatial planning in Ireland at the time of the application, identified Cork as a 'Gateway', the highest level in the NSS regional planning settlement hierarchy. As a Gateway it acts as an economic base to lever investment into the southwest region of the country.

The Southwest Regional Planning Guidelines (2010-2022) identifies the Port of Cork as a key component of its economy and its regional infrastructure and placed onus on the Local Authority to facilitate its expansion by identifying appropriate locations for port activities served by road transport. The objectives of the Cork Area Strategic Plan (CASP) to re-locate the existing port, while facilitating the rejuvenation of existing port area adjacent to the city for residential and amenity purposes, specifies the move is critical to securing the objectives of the NSS. The NSS emphasises the need for balanced regional development and interconnections between transport networks to enhance international access from all parts of the country and interchange between the national transport network, international airports and sea ports. The NSS also recognised the importance of sea ports and shipping services, including sea access from Cork.

Ireland's National Climate Change Strategy 2007-2012 which aims to deliver on Ireland's international obligations to reduce GHG emissions emphasises the need for modal shift through the infrastructural provisions of Transport 21, the then State Transport Investment Plan (now 'Transport for Ireland'). In addition, the Department of Transport's Policy 'Smarter Travel' (20092020) strategy makes reference to the need for the maritime transport sector to use less polluting fuels to meet international obligations. 
The National Port's Policy (Department of Transport, Tourism and Sport 2013) has a core objective to support a competitive maritime sector and identifies Cork as a Port of National Significance (Tier 1) and is included in the European TEN-T core network. These are described as ports that have the potential for high international connectivity which should be connected to the wider European rail and road network by 2030. The National Port's Policy envisages that the revised TEN-T programme will enable funding through the CEF. The policy outlines that the Ireland will need additional capacity post-2030 and Tier 1 ports must have the necessary capacity to ensure access to regional and global markets. While connectivity to rail is an objective of the policy it also notes that the majority of freight transport in Ireland is via road and will remain so for some time to come.

The South West Regional Planning Guidelines 2010-2022 while acknowledging the transport connectivity issues also identifies the Port of Cork as a key element of the regional economy and infrastructure. It regarded that there was an urgent requirement to identify and develop a new deep water port while helping to secure the redevelopment of the Cork City Docklands under the CASP.

This research indicates/suggested that the impact of regional spatial planning and governance was significant in achieving the project commitment as guaranteed by the range of local and state actors involved. The project therefore had the necessary fit in spatial planning terms within the national planning hierarchy (NSS) at the regional level. In addition, the project would facilitate the freeing up of a city land bank.

There is one TEN-T 'Core Network Corridor' in Ireland. It runs from The North Sea - Mediterranean Corridor, which stretches from Belfast in the north of Ireland (in the UK), to Cork and Dublin, through the UK, Belgium, Luxembourg and France. The Inspector's report on the $2^{\text {nd }}$ planning appeal made specific reference to the EU TEN-T Regulations 1315/2013 and noted that the TEN-T network needs to ensure efficient multi-modality for more sustainable modal modes of transport for both freight and passenger travel. In the context of Cork as a Core Port and the adjacent N28 national primary road, as part of the Core Network of roads within TEN-T, it was noted that Article 41 of TEN-T Regulations provides that maritime ports within the core network must be connected with rail and road networks by December 2030, except where physical constraints prevent this occurring. These issues proved to be of paramount importance during the planning consent process and had a bearing on the deliberations and stakeholder consultations on the Port re-development. The interviewee commented that the issue of port-freight-rail linkages was therefore a key issue of concern to the Local Authority when considering the first application for the development and the initial application was refused on traffic generation grounds due to a lack of a rail link. The Draft Strategic Framework for Investment in Land Transport (Department of Transport, Tourism and Sport 2014) outlines that regional distribution of port traffic will influence future transport investment in Ireland. The report acknowledges a shortfall in funding for heavy rail with the result road transport will remain the principal mode for air and seaport access. It states however that port capacity should not be constrained by this fact. The interviewee suggested that the $2^{\text {nd }}$ planning application had succeeded because it had been able to argue that the necessary plans were in place to manage traffic generation and linkages and this was accepted by the consenting authority.

The research and interviews indicated that the Strategic Infrastructure Development (SID) Act acted as a key piece of legislation that facilitated this particular project but interviews indicated major issues remained:

"Yes, the SID has made things easier but it depends on the project - the Cork Incinerator was difficult. The Cork port project had political backing, the SID was meant to speed up planning 
but this is not the case because applicants have now to go to various stakeholder/agencies and Prescribed Bodies [the bodies listed in the planning legislation that must be consulted for their views on particular planning cases] for consultation in advance to get their viewpoints and address them at pre-planning (consultation) stage".

Other issues raised included conflicts between spatial planning objectives and other compliance requirement for nature protection. The Habitats Directive and the requirements of AA (Appropriate Assessment) were seen by this interviewee to have: "complicated things ... EIA and AA focus for Local Authorities. Local Authorities have to do EIA screening for AA. It is very resource intensive now you have Europe; the Courts etc...".

In terms of funding the EU cohesion policy has a major influence but once the project becomes active in planning terms it is the local development plan and processes which are of most importance. Such projects are obviously reliant on significant funding and are unlikely to happen in the absence of such support.

The above all highlight the significance of the project in supporting regional and economic development and delivering on EU cohesion policy to reduce imbalances across European regions, in particular peripheral regions where transport accessibility continues to be an issue of importance. The influence of EU cohesion policy on spatial planning structure is evident as the spatial hierarchy and territorial governance underpinned the EU funded project. As an exemplar, the project demonstrates how joined up planning from national, through regional and local level plans can enable the actualisation of projects. It also illustrates new ways in which stakeholder consultation in planning processes are more managed within the Irish SID consultation framework but from a local perspective they still can remain cumbersome due the resourcing constraints of the Irish public service who participate as key consultees to planning.

It is evident that for transport and accessibility projects of this nature national planning investment agencies should plan the necessary requirements for inter-modal connections in advance of planning approval. This would reduce exposure to delays in the delivery of projects due to planning constraints based on projects being premature. The importance of having political support locally as well as priority recognition for the project within the various regional and national level documents is essential. This project was clearly referenced across numerous key documents and strategies in terms of spatial and national planning. This provided the necessary weight for the regional scale project and helped to secure planning consent.

\section{Plans, implementation and relationship between cohesion policy, spatial planning and territorial governance on an example of the Dublin International Airport - Terminal 2 project}

Ireland's Dublin Airport is an international connecting point on the TEN-T and therefore eligible for finance under one of European Investment Bank's priority lending objectives The development of Ireland's International Airport second terminal project (T2) in 2010, aimed to enhance the infrastructural capacity and consolidate the airport's international gateway status within the context of transport agencies, airlines, third parties and environmental policies. It was established under the NDP 2007-2013 (The Stationery Office 2007) supported by cohesion policy and the National Spatial Strategy 2002-2020.

Spatial planning in Ireland supports the implementation of operational programmes (OPs) and regional and sub-regional strategies provide the framework for their delivery and supports individual projects funded by OPs. Ireland has three regional assemblies. This practice case study is located in the Eastern Midland Regional Authority in the Greater Dublin Area. Local level 1 gov- 
ernance of planning in this region is managed by the Fingal Local Authority, the most northerly of Dublin's four local authorities.

Cohesion policy directed through the NDP pointed to the need for investment in Ireland's three state airports (Dublin, Cork and Shannon). To this end national funding was allocated under the NDP to upgrade road transport networks under Transport 21 (the M50, M1 and M3 roads) and other investments to support the expansion of the airport (i.e. Metros North and West and national and non-national roads). The decision to approve the expansion also had regard to Regional Planning Guidelines (RPGs, 2004-2006), the strategic transport policy for Dublin (Dublin Transportation Office, 2000) and the Fingal Local Authority Development Plan 2005-2011 and previous plans which had as their objectives to provide for east-west expansion and the Local Airport Local Area Plan. The Local Authority - Fingal in their Community Development Plan made provision for the airport expansion in line with the RPGs and outlined a comprehensive roads programme serving the airport and set aside lands specifically for the development of Metro North, the then planned (not yet delivered) first Irish 'underground' rail line.

Irish aviation policy has been described by an interviewee as somewhat "protracted", given that there was no overarching policy prior to 2015. Spatial planning policy documents did recognise the importance of the airport but only "low level policy" was available in the form of Local Area Plans and Development Plans at local level 1 to underpin its development. This meant that the consultation with key stakeholders in connection with the proposed expansion was never clear cut. A new national aviation policy was put in place in 2015 (Department of Transport, Tourism and Sport 2015) and is important to the development of $\mathrm{T} 2$ as it provides an overarching aviation policy or "superstructure around aviation" that hitherto was absent in Ireland.

The enabling Irish planning legislation, the Planning and Development Act (Irish Statute Book No. 30, of 2000) provides a number of opportunities for consultation with stakeholders and public participation in line with the Aarhus Convention on the right to public participation in planning (UNECE 1998) and the Directive on Public Participation (2003/25/EC). Pre-planning consultation with stakeholders and with local government is afforded on proposed developments under the Planning and Development Act. Public participation in planning is facilitated by means of making submissions on planning applications prior to development consent and both first and third-party appeals are allowed against planning decisions made by local authorities. An interviewee was of the view that participation can be problematic however, in some instances: "Aarhus (Convention and Directive on the right to public participation in environmental decision making) in Ireland you don't need any locus standi to make a submission".

This interviewee explained that the Irish planning process can be seen by applicants to be cumbersome and sometimes mired by delays due the high level of participation and consultation afforded: (As part of standard pre-planning process) "The proponents of applications must consult with national bodies, transport bodies (e.g. National Transport Authority, Transport Infrastructure for Ireland) and sit down with them (to discuss the project), not necessarily at speed. The intent is good but they (proponents) could be caught by different perspectives, it just takes time e.g. surface access (i.e. transport linkages), getting approval or alignment is a lengthy process".

In the case of T2, public transport access was a key issue that the Dublin Airport Authority had to address with relevant stakeholders during the planning consent process. The Inspector's report on the planning application (An Bord Pleanala, 2006/PL06F.220670) reviewed the adequacy of the Environmental Impact Assessment (EIA) in this regard. The final preferred site was selected on the basis of road access and proximity to the (then) proposed underground, a Ground Transportation Centre, bus terminus and car parking. The transport elements of the EIA were 
considered adequate and robust by the Inspector; however several stakeholders including Ryanair, An Taisce - The National Trust for Ireland, and residents, raised concerns about transport and traffic generation issues arising from increased passenger numbers, as well as concerns about conflict with national and international commitments to reduce GHG emissions. There is a need for pre-planning consultations with transport stakeholders, to discuss how surface access would be facilitated and to discuss modal split options. Transport issues proved to have a key influence on the planning case as conditions were attached to final consent approval placing a cap on passenger numbers to 35 million passengers per annum.

Stakeholder consultation can therefore lead to significant alterations in outcomes for project delivery and can create time delays which can be costly for proponents. The introduction of the Planning and Development (Strategic Infrastructure) Act (SID) 2006 (No. 27 of 2006) can be viewed by industry sources as a positive measure to address the delays associated with planning in Ireland. Section 37(a) 2 of the SID Act requires that developments in the categories listed in the Seventh Schedule of the Act ${ }^{14}$ that are deemed (a) 'strategic' in nature (i.e. of economic or social importance to the country or region); (b) would contribute to national spatial and/or regional planning objectives or (c) would have significant effect on the area of one or more planning authority, are sent directly to the Irish Planning (Appeals) Board, An Bord Pleanala, for planning approval, rather than to the local authority. In effect the process limits the possibility of third party appeals but maintains the right for pre-planning consultation and public submissions on SID applications. In the case of T2 the application was deemed to be a SID project. Prior to the application, Dublin Airport Authority carried out pre-planning consultations with various stakeholders including Fingal Local Authority (local level 1) and the Department of Transport (national level) and the Irish Rail Procurement Agency (RPA)/Transport Infrastructure for Ireland (TII) (national level), to discuss issues around modal split and growth in passenger numbers. In terms of cooperation between agents an interviewee stated: "Don't think there is a difficulty (with the process of cooperation and consultation per se) but there is a significant time difference between how long it takes for each agent to make a decision (during pre-planning consultations with the various agents involved) (it's a question of) efficiency of resources (within the various agencies, which might be stretched). Dividing the project up into work streams (is good). There will always be stumbling blocks, once you get into planning (it's more efficient) but pre-planning consultation can take up to 2 years".

In terms of models of good practice in Ireland the interviewee also indicated that aligning the NPF (Government of Ireland 2017) with the (proposed) National Investment Plan (NIP) and specific planning strategies would facilitate more joined up planning and ensure that projects could come to fruition more seamlessly. In the last twenty years European Investment Bank loans have been used for aviation in tandem with the NDP that was supported through cohesion policy.

\section{Conclusions}

The examples and practices demonstrate the impacts of cohesion policy at the strategic level and civil society level as:

- Cohesion policy was directed through the National Development Plans for large projects in tandem with other EU funding.

- Legislation changes were enacted to enable fast track delivery mechanisms for strategic infrastructure projects

\footnotetext{
$\overline{14}$ Energy, Transport and Environmental infrastructure.
} 
Examples on the strategic level, to improve parity and connectivity at the EU regional level on National Transport projects are the Cork Port tier 1 and Dublin International Airport. They demonstrate cohesion policy projects directed through the NDP working in tandem with European Investment Bank and TEN-T policies. National legislation was adapted to fast track such strategic projects with the Strategic Infrastructure Development Act 2006. This top down mechanism for delivering large scale projects have worked well and are in contrast to other major infrastructure projects such as the Corrib natural gas pipeline, over ground pylons for Eirgrid and the restructuring of water infrastructure and associated charges controversies. These experiences indicate the importance of the focus on engagement at civil society level and value of including communities at the strategic level earlier on in the process.

The connectivity between regional and local would be particularly important now that the regional assemblies have a stronger role in the management of EU project participation such as INTERREG, LEADER and PEACE. While cohesion policy thematic objectives and priorities work well at regional level, a less centralised, flexible approach that allows local communities autonomy to propose their place based requirements is essential in developing local economies and encouraging competitiveness.

Spatial policies rather than sectoral, seem to work best where the local development agenda require flexibility of approach. It remains to be seen if the new regional spatial and economic strategies will provide this with sufficient political leadership and understanding. The lessons from past Irish urban policy changes shows that both a strong political commitment and dedicated resourcing are essential to support new directions in policy. In addition this support must be long term and across the political spectrum as the cyclical nature of development patterns means that delays and time lags are inevitable. The availability of EU funding and resources is both a necessity and a useful external reference framework within which strategic planning decisions for the regions of Ireland are adopted and implemented.

It is clear that the availability of EU cohesion policies assisted the investment in planned regional infrastructure and developments. As a peripheral economy in the EU this can be argued to assist economic and social development at a national level. Within the regions of Ireland significant problems in terms of economic and social development in rural areas remain and significant further attempts at addressing such imbalances are clear in evolving planning policy as represented in the new NPF. Even with a major economic recovery, clear deficits remain in infrastructure, housing and the provision of broadband IT for rural areas.

Ireland by comparison with other EU states provides an interesting comparison of the operation of a development led spatial planning policy framework. This approach can be identified as a contributory factor to the previous property market collapse and major economic recession of 2008 to 2012. This period saw sustained high levels of speculative development activity linked to questionable zoning and planning decisions contributing to a subsequent property market collapse. This necessitated the rescue of the Irish owned and managed banking sector and property market at a major cost to the exchequer.

While other EU states move towards a more localised spatial planning approach, the new urban and regional policy ambition in Ireland as expressed in the NPF of 2018 is to move towards a comprehensive approach. This involves integrated rational planning and linked public sector investment in transportation and infrastructure. Past EU funding has played a significant role in ensuring that long term infrastructure and development planning at a strategic level developed a more coherent organised approach. The influence of EU policy can be seen in shifting the national planning system towards a more strategic and regional approach from the previously 
local development led approach. In addition, the financial planning central to EU support has made the initiation and implementation of major strategic infrastructure investments more realistic in terms of both initiation and implementation

\section{Endnote}

The material for this article was developed from research carried out on the ESPON COMPASS Project - Comparative Analysis of Territorial Governance and Spatial Planning Systems in Europe under the direction of Brendan Williams and Zorica Nedova Budic at UCD, the ESPON COMPASS Case Study Ireland report by Johanna Varghese and Deirdre Joyce and a conference presentation by Brendan Williams on the ESPON COMPASS project at Regional Spatial Strategies: the Architecture of Effective Regional Development at the Department of Housing, Planning and Local Government, Custom House, Dublin in May 2018.

\section{References}

An Bord Pleanala, 2014. Inspector's Report. Strategic Infrastructure Application under Section $37 E$ of the Planning and Development Act 2000 (as amended). PL04.PA0035, http://www.pleanala.ie/ documents/reports/REP/PA0/RPA0035A.pdf [3 October 2017].

An Bord Pleanala, 2006. Report on Transportation Aspects of Planning Appeal for Second Terminal and Associated Works at Dublin Airport. Appendix 5. Planning Refs. PL06F.220670/PA F06A/1248, http://www.pleanala.ie/documents/reports/220/R220670B.pdf [21 September 2017].

Bord lascaigh Mhara, 2017. www.bim.ir: http://www.bim.ie/ [1 May 2018].

Brennan M. A., Flint C. G., Luloff, A. E., 2009. Bringing Together Local Culture and Rural Development: Findings from Ireland, Pennsylvania and Alaska. Sociologia Ruralis, vol. 49, no. 1, pp. 97-112.

Brezzi M., Dijkstra L., Ruiz V., 2011. OECD Extended Regional Typology: The Economic Performance of Remote Rural Regions. OECD Regional Development Working Papers, 2011/06, OECD Publishing, http://dx.doi.org/10.1787/5kg6z83tw7f4-en [3 October 2017].

Commssion for the Economic Development of Rural Areas, 2017. www.chg.gov.ie/app/uploads/2017/01/ reviltalising-irelands-towns-v1.pptx [1 May 2018].

Cork City Council, 2001. Cork Area Strategic Plan (CASP, 2001-2020). http://www.corkcity.ie/casp/strategicplan/ [11 October 2017].

Cork Equal and Sustainable Communities Alliance, 2015. CESCA Area Profile Cork City. http://www.cesca. ie/assets/cesca-area-profile-may-2015.pdf [11 April 2018].

Coveney S., 2017. National Planning Framework 2040 Roadshow. Dublin.

Department of Environment, Community and Local Government, 2015. Guidelines on Local Economic and Community Plans. http://drcd.gov.ie/wp-content/uploads/local_economic_and_community_ plans.pdf [1November 2018].

Department of Environment, 1997. Sustainable Development - A Strategy for Ireland. https://www. housingagency.ie/Our-Publications/Archive/Regeneration/Sustainable-Communities-A-guide-forIreland_1997.aspx [1 November 2018].

Department of Housing, Planning and Local Government, 2017. Ireland 2040 Our Plan: Draft National Planning Framework. http://npf.ie/wp-content/uploads/2017/10/Ireland-2040-Our-Plan-Draft-NPF. pdf [23 October 2018].

Department of Housing, Planning and Local Government, 2018. Planning Guidelines, 28, https://www. housing.gov.ie [2 April 2019]. 
Department of Transport, Tourism and Sport, 2013. The National Port's Policy. http://www.dttas.ie/ sites/default/files/node/add/content-publication/National\%20Ports\%20Policy\%202013.PDF ]5 October 2017].

Department of Transport, Tourism and Sport, 2014. The Draft Strategic Framework for Investment in Land Transport. http://www.dttas.ie/sites/default/files/publications/corporate/english/ public-consultation-investing-our-transport-future/consultation-sfilt-investing-our-transport-future-steering-group-report.pdf [6 October 2017].

Department of Transport, Tourism and Sport, 2015. A National Aviation Policy for Ireland. http://www. $\mathrm{dttas.ie/sites/default/files/publications/aviation/english/national-aviation-policy-ireland/nation-}$ al-aviation-policy-ireland.pdf [18 September 2017].

Department of Transport, 2009. 'Smarter Travel' 2009-2020: A Sustainable Transport Future, A New Transport Policy for Ireland 2009 - 2020. http://www.smartertravel.ie/sites/default/files/ uploads/2012_12_27_Smarter_Travel_english_PN_WEB\%5B1\%5D.pdf [4 October 2017].

Dublin Transportation Office, 2000. A Platform for Change. Final Report. An Integrated Transportation Strategy for the Greater Dublin Area 2000-2016. https://www.nationaltransport.ie/downloads/ archive/platform_for_change_2001.pdf [11 September 2017].

Eastern Midland Regional Assembly, 2015. Planning and Economic Role of the Regional Assembly. Presentation, http://emra.ie/dubh/wp-content/uploads/2015/02/Item-6 [9 April 2019].

Eastern Midland Regional Assembly, 2017. Regional Spatial and Economic Strategy - Issues Paper. http:// emra.ie/dubh/wp-content/uploads/2017/11/EMRA_IssuesPaper_Nov17.pdf [1 January 2018].

EPA, 2011. Barriers to Sustainable Transport in Ireland. Report Series no. 7, http://www.epa.ie/pubs/ reports/research/climate/CCRP\%20Report\%20Series\%20No.\%207\%20-\%20Barriers\%20to\%20Sustainable\%20Transport\%20in\%20Ireland.pdf [1 June 2018].

Fallon P., 2017. Interview for ESPON (J. Varghese, Interviewer).

Fingal County Council, 2005. Fingal Development Plan 2005-2011. https://www.fingal.ie/planning-and-buildings/development-plans-and-consultations/previous-fingal-development-plan/ fingaldevelopmentplan2005-2011/ [18 September 2017].

Fingal County Council, 2015a. Fingal Local Economic and Community Plan. http://www.fingalcoco.ie/ business-and-economy/localeconomicandcommunityplan/ [14 January 2018].

Fingal County Council, 2015b. Fingal Local Economic and Community Plan 2016-2020. http://fingal.ie/ media/Fingal\%20Local\%20Economic\%20Community\%20Plan\%202016\%20-\%202020.pdf [11 January 2018].

Fingal County Council, 2016. Press Release (22 June 2016\}. http://www.fingalcoco.ie/media/Local\%20 Economic\%20Community\%20Plan\%20Launch\%20PRESS\%20RELEASE\%20230916.pdf [11 January 2018].

Gleeson C., 2016. News-social affairs Census 2016: Rural isolation and transport to become issues. https://www.irishtimes.com/news/social-affairs/census-2016-rural-isolation-and-transport-to-become-issues-1.2722272 [6 January 2018].

Government of Ireland, 2017. Draft National Planning Framework, Ireland 2040: Our Plan. http://www. housing.gov.ie/planning/national-planning-framework/ireland-2040-our-plan-draft-national-planning-framework [18 September2017].

Government Publications, 2002. National Spatial Strategy 2002-2020, People, Places and Potential.

Government Publications, 2007. National Development Plan (NDP) 2007-2013.

Graham, A., 2017. News (20 June 2017). http://www.engineersjournal.ie/2017/06/20/dublin-congestion-e2bn-in-2033-without-corrective-action/ [5 January 2018].

Irish Gvernment News Service, 2016. Releases (11/2016). https://merrionstreet.ie/en/News [5 January 2018].

Lynch C., 2017. Participation Process in Ferbane Development Plan (J. Varghese, Interviewer).

McHenry H., 2017. Western Development Commission Insights - what is rural? http://www.wdc.ie/category/wdc-insights/population/ [15 January 2018].

National Planning Framework, 2017. http://npf.ie/wp-content/uploads/2017/10//reland-2040-OurPlan-Draft-NPF.pdf [23 October 2017]. 
Ni Aodha G., 2017. Small towns 'hit hardes' in the past 10 years, Dublin least affected. http://www.thejournal.ie/small-towns-deprived-3687306-Nov2017/ [7 January 2018].

Nolan M., 2016. Transport Infrastructure Ireland. www.engineersireland.ie [6 January 2018].

Northern and Western Regional Assembly, 2017a. Northern and Western Regional Assembly - About. http://www.nwra.ie/about/ [5 January 2018].

Northern and Western Regional Assembly, 2017b. Regional Spatial and Economic Strategy - Issues Paper. http://www.nwra.ie/wp-content/uploads/NWRA-RSES-Issues-Paper.pdf [5 January 2018].

O'Keefe B., 2017. Interview with stakeholder (J. Varghese, Interviewer).

Planning and Development Act, 2000. Irish Statute Book, No. 30, of 2000.

Regling K., Watson M., 2010. A Preliminary Report on The Sources of Ireland's Banking Crisis. Government Publications Office, Dublin.

Riordan P., 2017. Policy Fields and Spatial Planning (J. Varghese, Interviewer).

Smyth P., 1998. $1125 \mathrm{~m}$ in EU funds for Luas are reallocated, mostly for Dublin (26 June 1998). The Irish Times, https://www.irishtimes.com/news/125m-in-eu-funds-for-luas-are-reallocated-mostly-fordublin-1.166870 [19 January 2018].

Southern Regional Assembly, 2016. Resources FAQ's. http://www.southernassembly.ie/resources/faqs [15 October 2017].

Southern Regional Assembly, 2017a. News Article Four facts you might not know about Europe - Ireland. http://www.southernassembly.ie/news/news-article/4-facts-you-might-not-know-about-europeireland [19 January 2018].

Southern Regional Assembly, 2017b. Regional Spatial and Economic Strategy - Issues Paper. http:// www.southernassembly.ie/regional-planning/regional-spatial-and-economic-strategy [3 January 2018].

Tosics I., Szemző H., Illés D., Gertheis A., Lalenis K., Kalergis D., 2010. EU Plurel Report 2.2.1. National spatial planning policies and governance typology. http://www.plurel.net/ [6 January 2018].

Teagasc, 2014. Rural Economic Development in Ireland. https://www.teagasc.ie/media/website/publications/2014/Rural_Economic_Development_in_Ireland.pdf [5 January 2017].

UNECE, 1998. Convention on Access to Information, Public Participation in Decision-Making and Access to Justice in Environmental Matters. https://www.unece.org/fileadmin/DAM/env/pp/documents/ cep43e.pdf [18 September 2017].

Williams B., Nedovic-Budic Z., 2016. The real estate bubble in Ireland. Policy context and responses. Urban Research \& Practice, vol. 9, no. 2, pp. 204-218, https://doi.org/10.1080/17535069.2016.11 74401. 